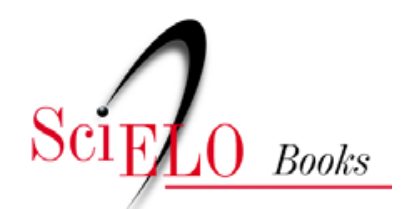

\title{
Capítulo 4 - Levantamento das habilidades pedagógicas e das conceituações das professoras das Salas de Recursos Multifuncionais
}

\author{
Carolina Rizzotto Schirmer \\ Leila Regina d'Oliveira de Paula Nunes \\ Stefhanny Paulimineytrick Nascimento Silva
}

\section{SciELO Books / SciELO Livros / SciELO Libros}

SCHIRMER, C. R., NUNES, L. R. O. P., and SILVA, S. P. N. Levantamento das habilidades pedagógicas e das conceituações das professoras das Salas de Recursos Multifuncionais. In: NUNES, L. R. O. P., and SCHIRMER, C. R., orgs. Salas abertas: formação de professores e práticas pedagógicas em comunicação alternativa e ampliada nas salas de recurso multifuncionais [online]. Rio de Janeiro: EDUERJ, 2017, pp. 87-116. ISBN: 978-85-7511-452-0. Available from: doi: 10.7476/9788575114520.006. Also available in ePUB from: http://books.scielo.org/id/xns62/epub/nunes-9788575114520.epub.

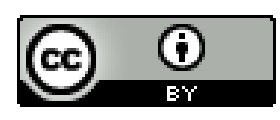

All the contents of this work, except where otherwise noted, is licensed under a Creative Commons Attribution 4.0 International license.

Todo o conteúdo deste trabalho, exceto quando houver ressalva, é publicado sob a licença Creative Commons Atribição 4.0.

Todo el contenido de esta obra, excepto donde se indique lo contrario, está bajo licencia de la licencia Creative Commons $\underline{\text { Reconocimento 4.0. }}$ 


\title{
Capítulo 4 - Levantamento das habilidades pedagógicas e das conceituações das professoras das Salas de Recursos Multifuncionais
}

\author{
Carolina Rizzotto Schirmer \\ Leila Regina d'Oliveira de Paula Nunes ${ }^{2}$ \\ Stefhanny Paulimineytrick Nascimento Silva ${ }^{3}$
}

\section{Objetivos}

Este estudo teve como objetivo identificar as habilidades das professoras acerca do emprego de recursos de Comunicação Alternativa e Ampliada (CAA) e de conhecimentos sobre temas afins antes e após o curso de formação continuada em serviço.

1 Professora adjunta da Faculdade de Educação da UERJ. E-mail: ead.carolina@gmail. com.

2 Professora titular da Faculdade de Educação e do Programa de Pós-Graduação em Educação da UERJ. E-mail: leilareginanunes@terra.com.br.

3 Mestranda em Educação pelo Programa de Pós-Graduação em Educação da UERJ. E-mail: stefhannyp@gmail.com. 


\section{Procedimentos}

O presente estudo foi desenvolvido na Oficina Vivencial, no Instituto Helena Antipoff. A coleta de dados foi realizada por meio de dois questionários, aplicados em duas ocasiōes. O primeiro continha 25 questões de múltipla escolha - que envolveram o emprego de recursos de CAA e de acesso ao computador - e tinha como objetivo identificar as habilidades dos professores. Sua elaboração foi baseada no questionário validado por Pelosi (2008). O segundo questionário era composto de 11 questóes abertas e pretendia verificar o conhecimento e a percepção dos professores sobre temas como deficiência, CAA, Informática Acessível e outros. A elaboração desse questionário foi fundamentada no instrumento validado por Schirmer (2012).

A primeira aplicação ocorreu em maio de 2013 , bem no começo da pesquisa, e a segunda, em dezembro de 2014, ao final do segundo ano de formação.

Foram realizadas análises quantitativas das questōes de múltipla escolha e de conteúdo das questôes descritivas. Utilizou-se a técnica de análise categorial, que funciona por operações de desmembramento do texto em categorias, segundo reagrupamentos analógicos (Bardin, 1977). A análise de conteúdo foi organizada em três etapas: a pré-análise, a exploração do material e o tratamento dos resultados que envolveram a inferência e a interpretação. Os dados coletados foram organizados em banco de dados, usando-se o software Microsoft Office Excel, o que auxiliou na organização dos dados em categorias para facilitar a análise, bem como na quantificação dos resultados, possibilitando a criação de gráficos ilustrativos.

Como nem todas as 18 professoras participantes do estudo responderam aos questionários nas duas datas, optou-se, para fins de comparação, por apresentar os dados de dez professoras que cumpriram o agendamento. 


\section{Resultados}

A seguir, são apresentados os dados do primeiro questionário analisado.

Gráfico 1 - Professora é capaz de determinar respostas afirmativas e negativas do aluno que não tem comunicação oral

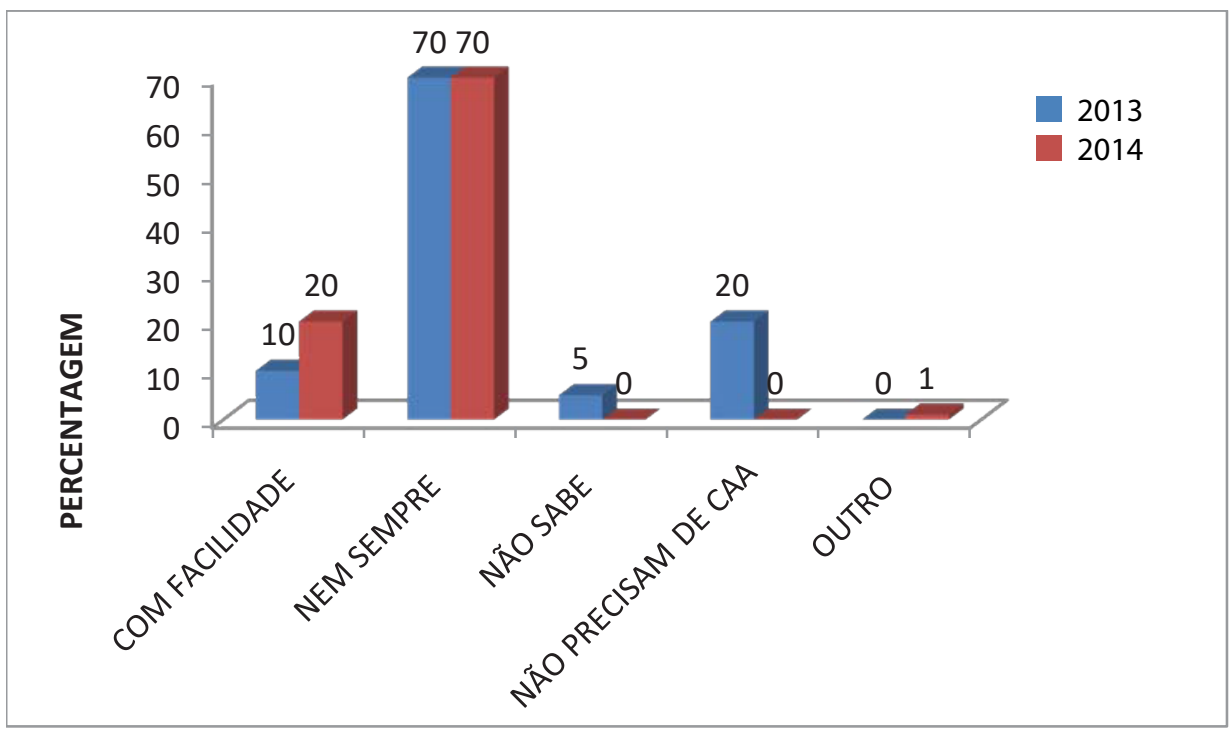

O número de docentes que sabiam determinar respostas afirmativas e negativas do aluno não oralizado aumentou levemente depois da formação de professoras. 
Gráfico 2 - Professora sabe utilizar adaptações para escrita (engrossadores, lápis especiais, órteses)

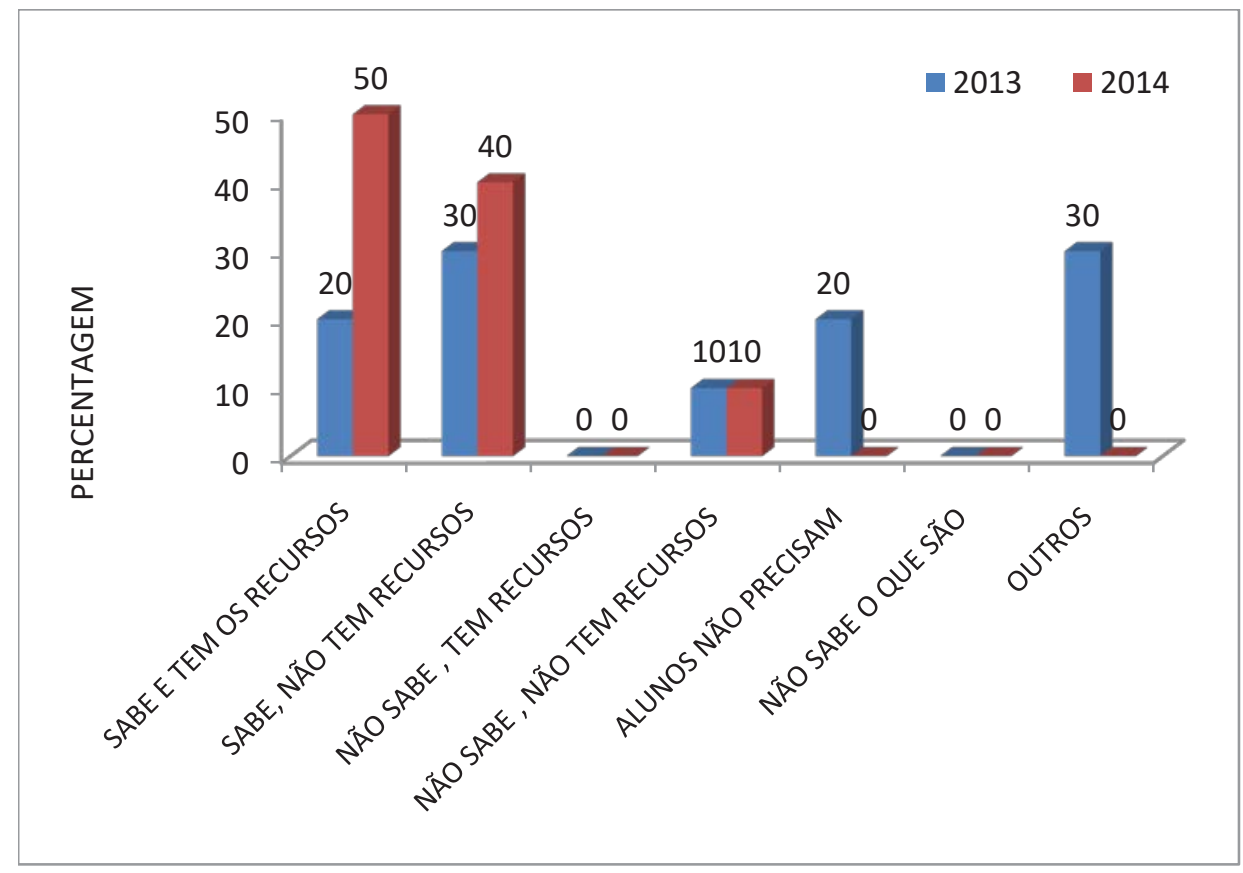

Após a formação, aumentou o número de professoras que informaram saber mais e ter mais recursos para fazer adaptações para a escrita. 
Gráfico 3 - Professora é capaz de elaborar prancha de comunicação

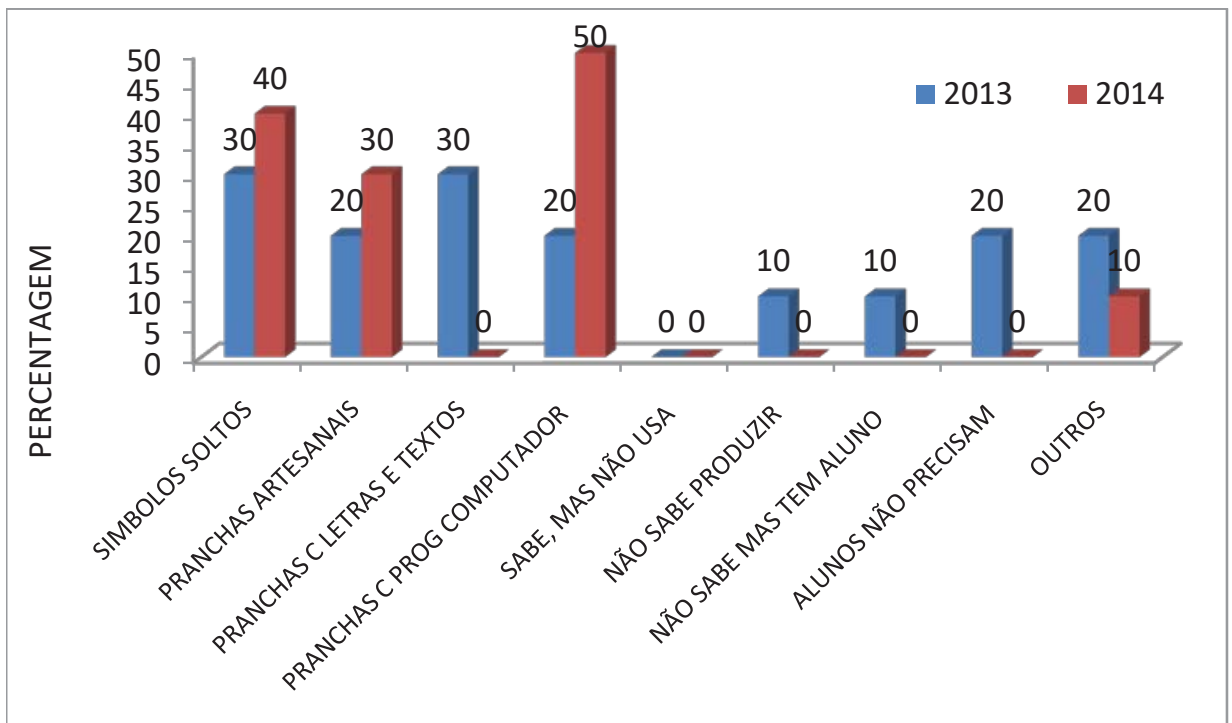

Aumentou o número de professoras que, após receberem a formação, passaram a elaborar recursos diversos de Comunicação Alternativa e Ampliada.

Gráfico 4 - Professora utiliza pranchas de comunicação socialmente

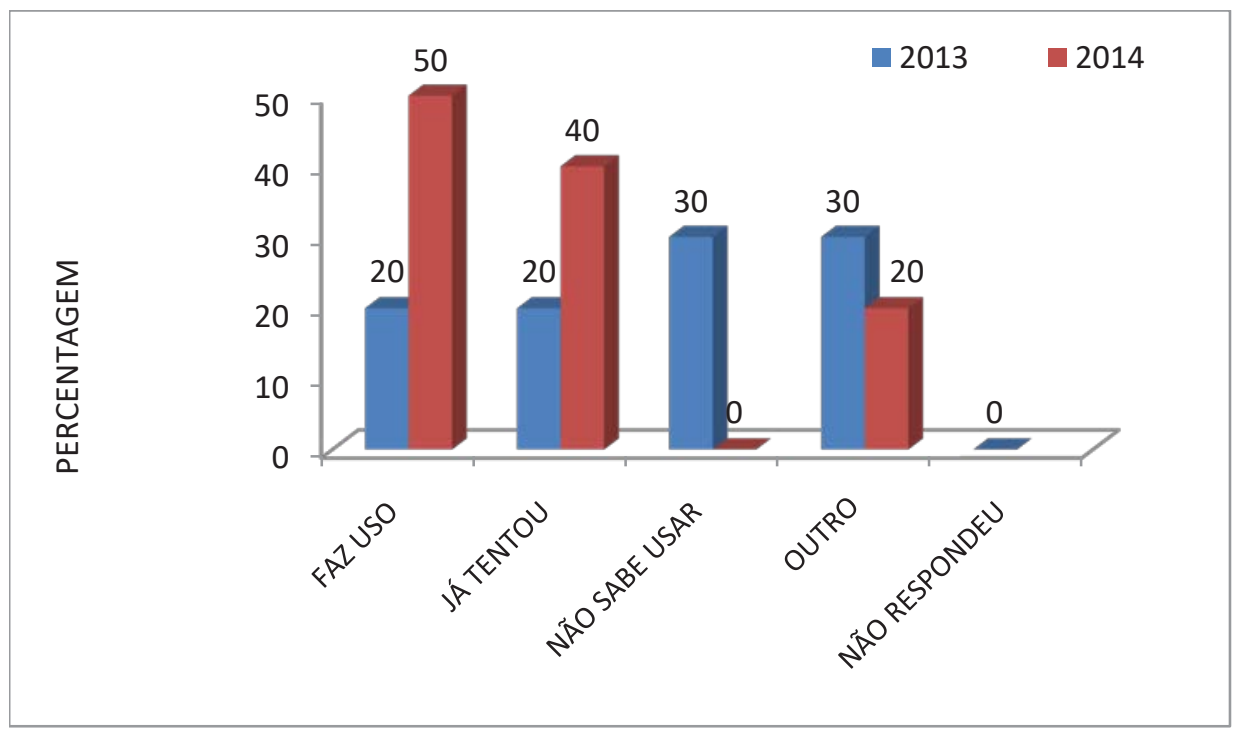


Maior número de professoras passou a usar ou a tentar usar a prancha de comunicação socialmente, após a formação.

Gráfico 5 - Professora utiliza prancha de comunicação para auxiliar no trabalho escolar

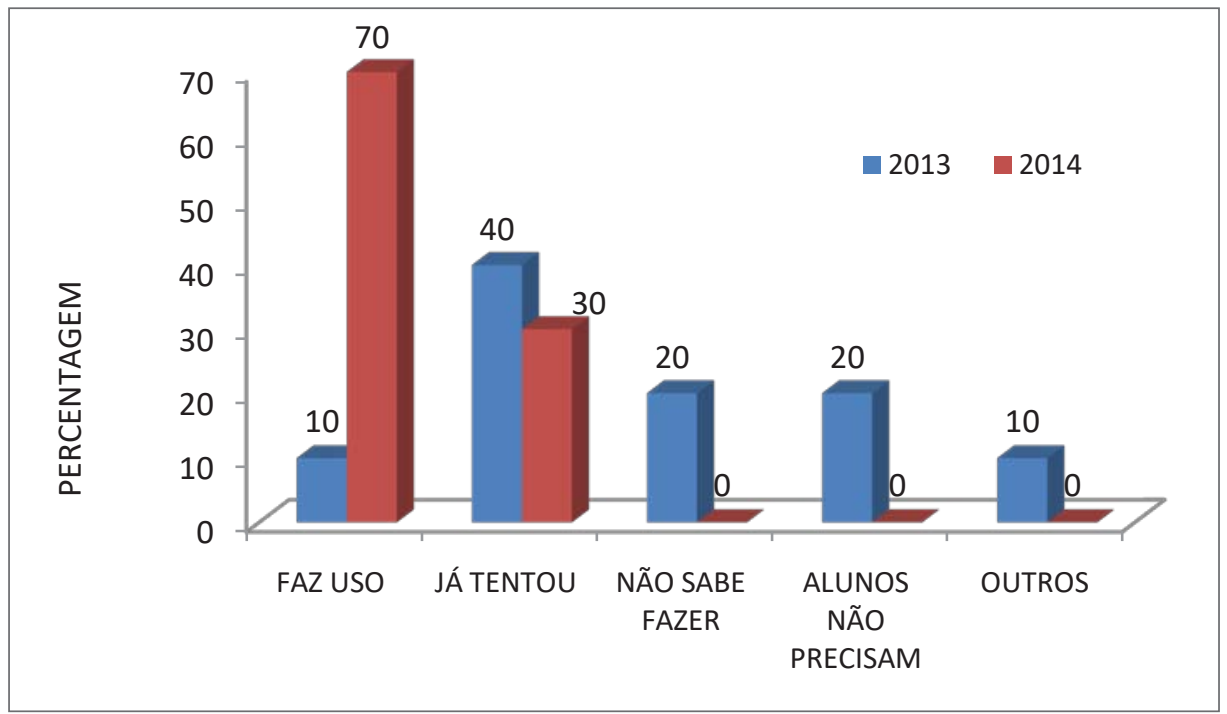

Houve um aumento considerável do número de professoras que passaram a usar pranchas de comunicação para fins acadêmicos após a formação.

Gráfico 6 - Professora faz adaptação de trabalhos escolares

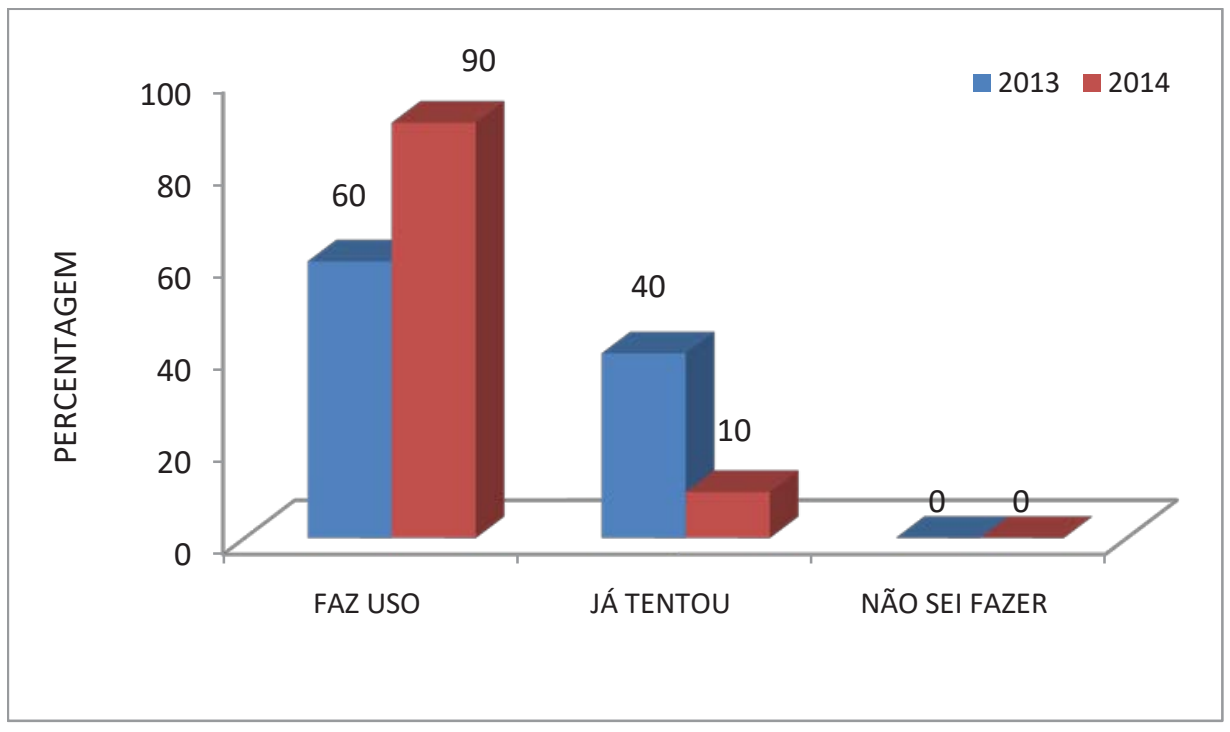


Com a formação, mais professoras passaram a fazer adaptação de trabalhos escolares.

Gráfico 7 - Professora usa letras emborrachadas e outros materiais adaptados para facilitar a escrita de alunos com dificuldade motora

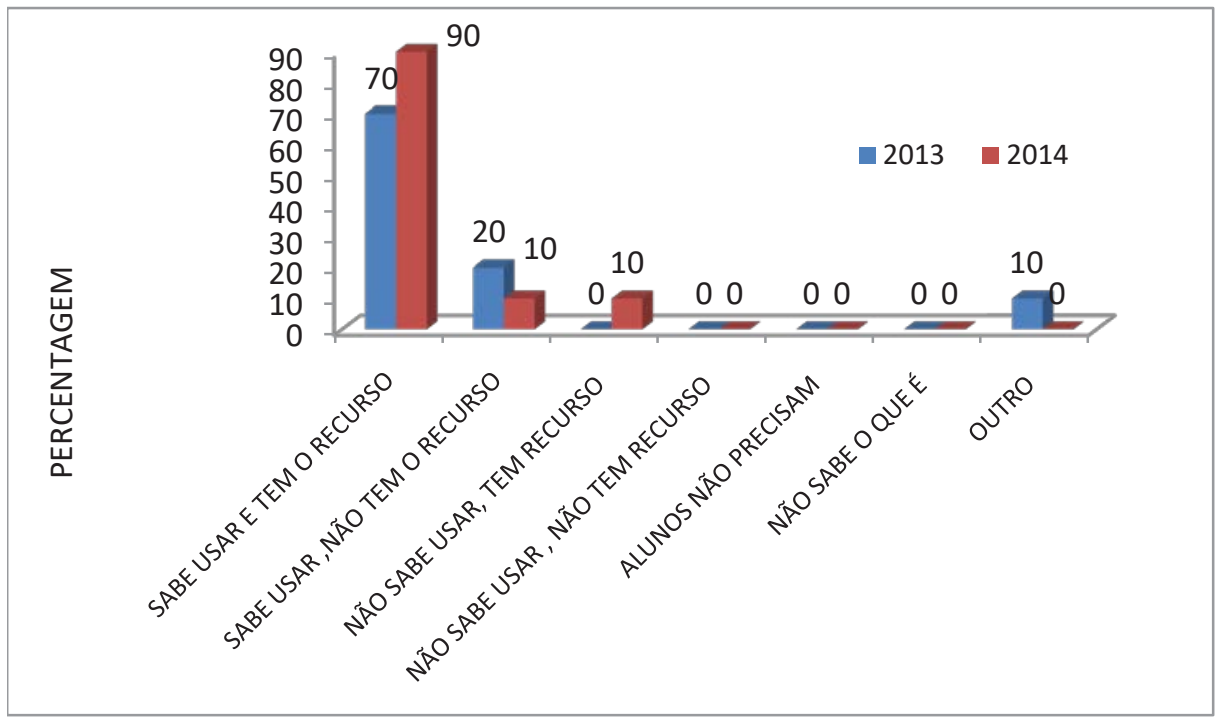

Após a formação, mais professoras passaram a empregar letras emborrachadas e outros materiais adaptados, a fim de facilitar a escrita de alunos com dificuldade motora. 
Gráfico 8 - Professora sabe avaliar o aluno para uso do acionador

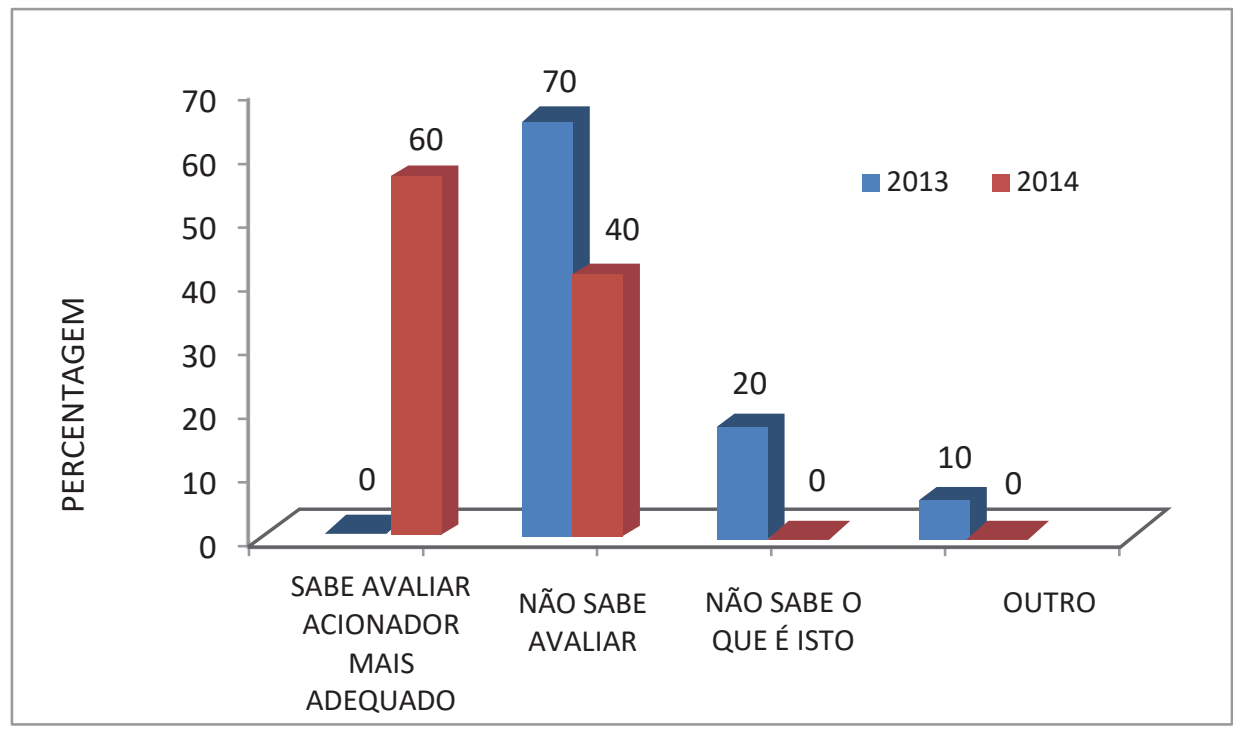

Após o curso de formação, um maior número de professoras passou a avaliar o aluno a fim de selecionar o melhor acionador. 
Gráfico 9 - Professora usa acionador

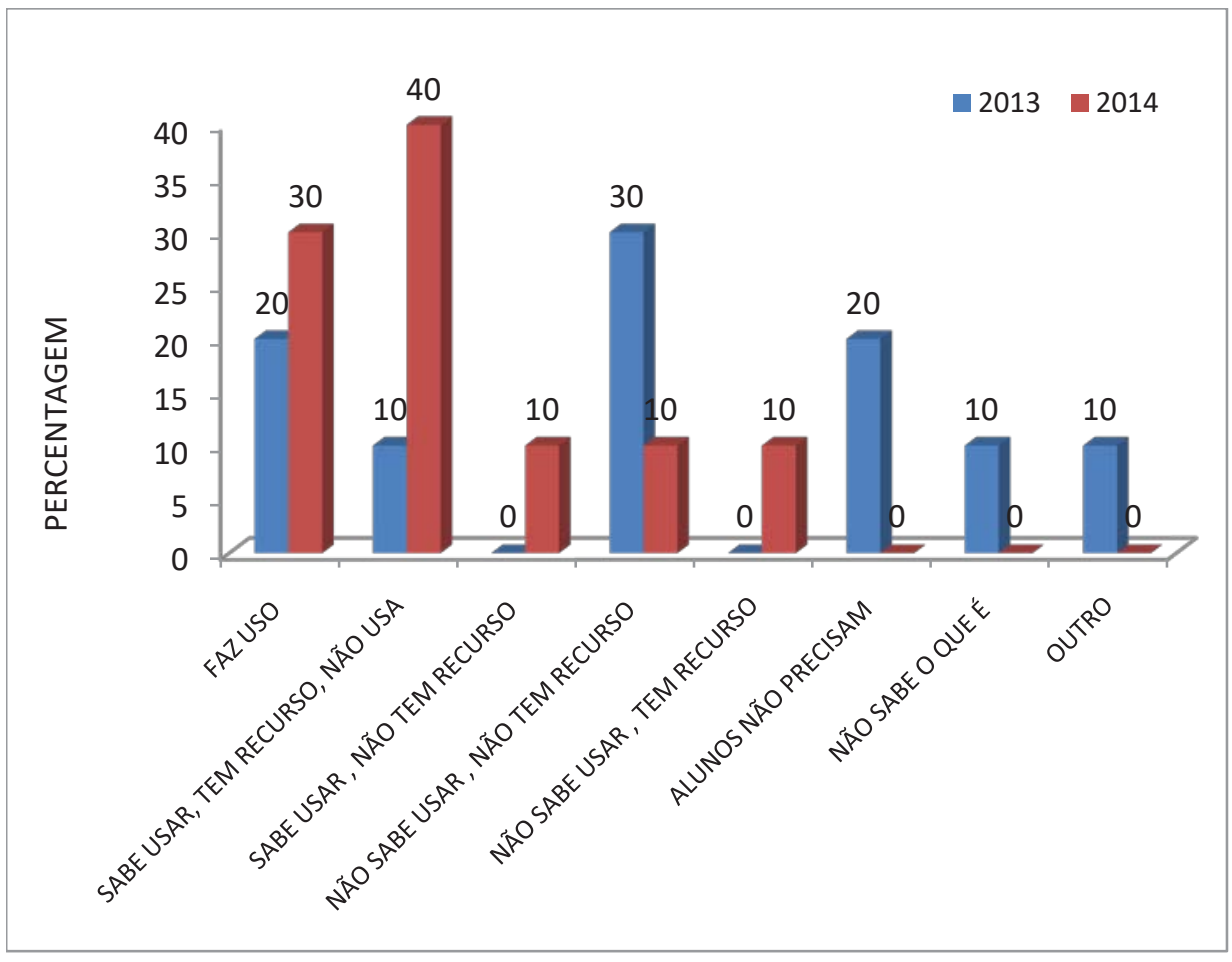

Mais professoras passaram a usar o acionador após a formação. No entanto, aquelas que não o usavam em 2013 continuaram a não fazê-lo em 2014. 
Gráfico 10 - Professora usa brinquedo adaptado (com interruptor de pilha)

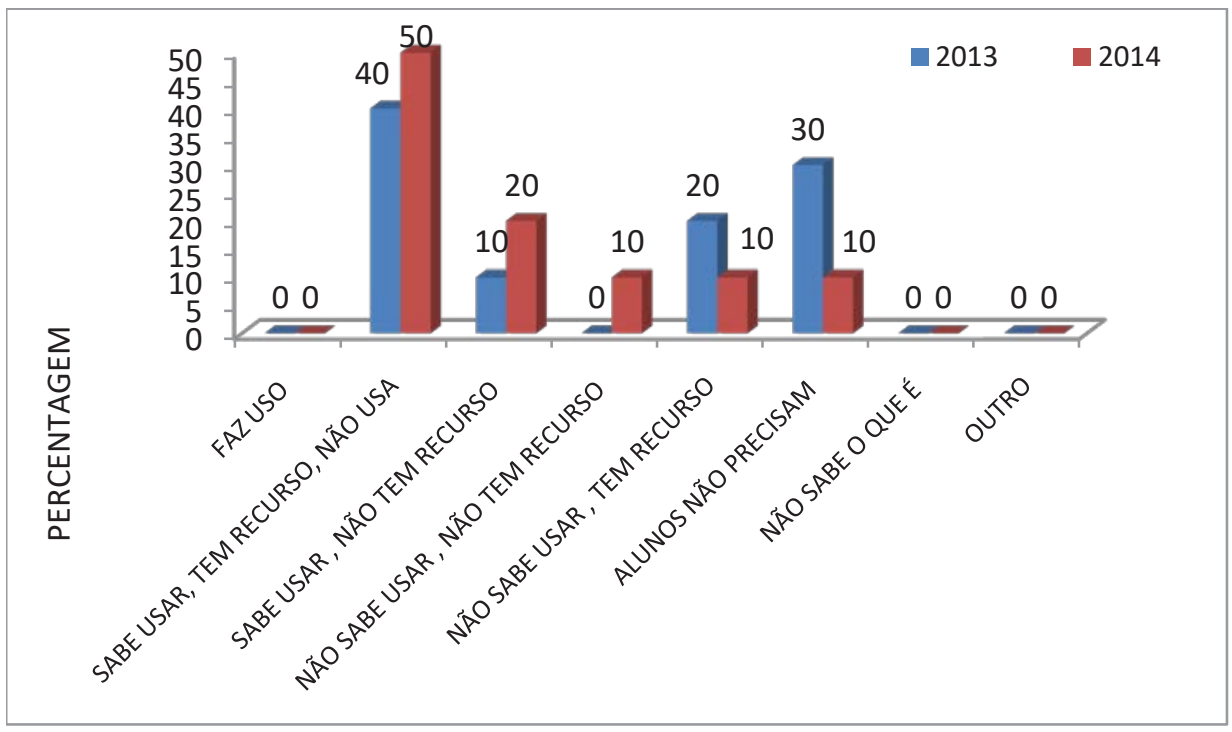

As professoras que possuem brinquedo adaptado não fazem uso deste. 
Gráfico 11 - Professora usa comunicador com voz

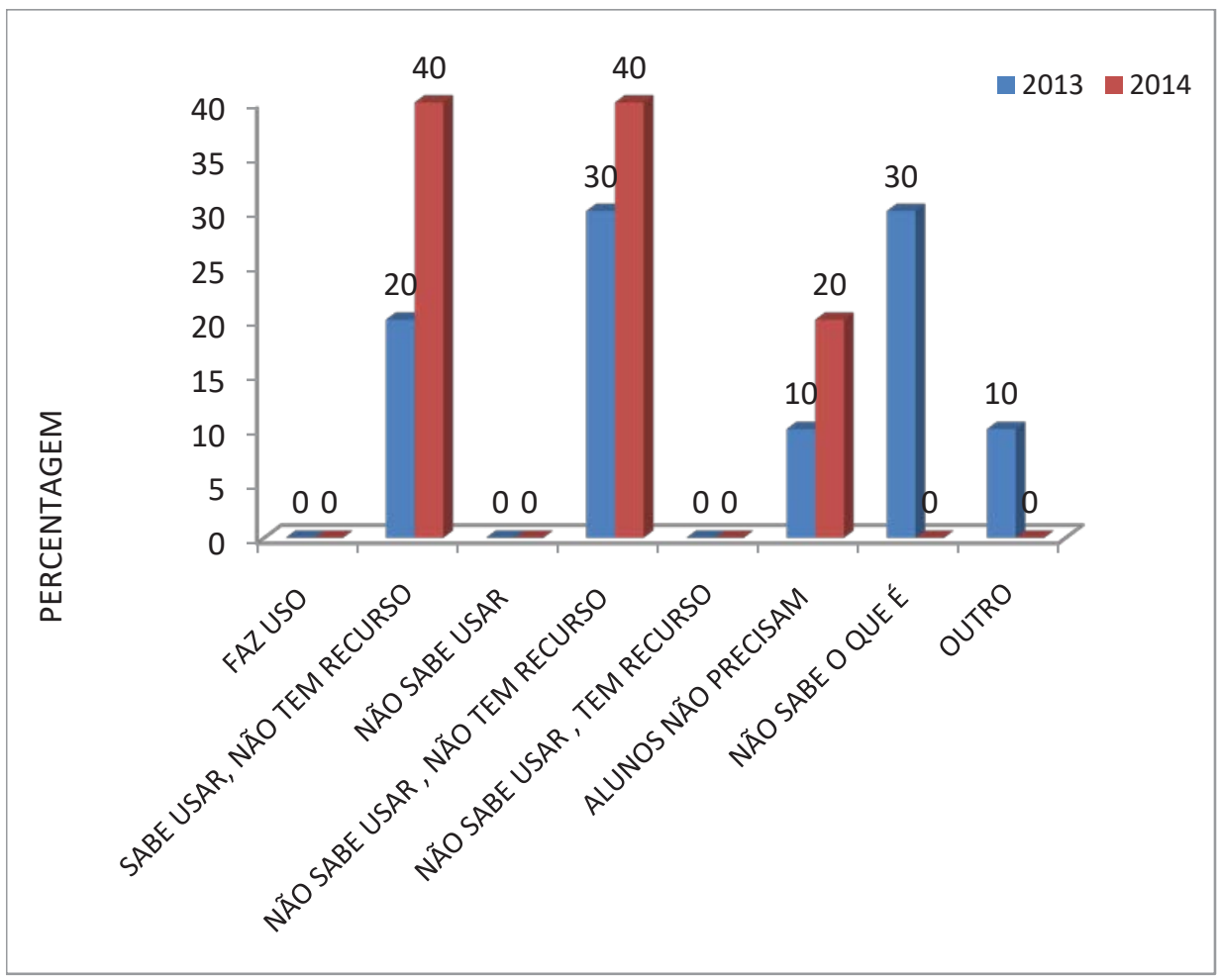

Professoras não possuem o comunicador com voz em suas salas. 
Gráfico 12 - Professora avalia aluno e determina a melhor forma de acesso ao computador

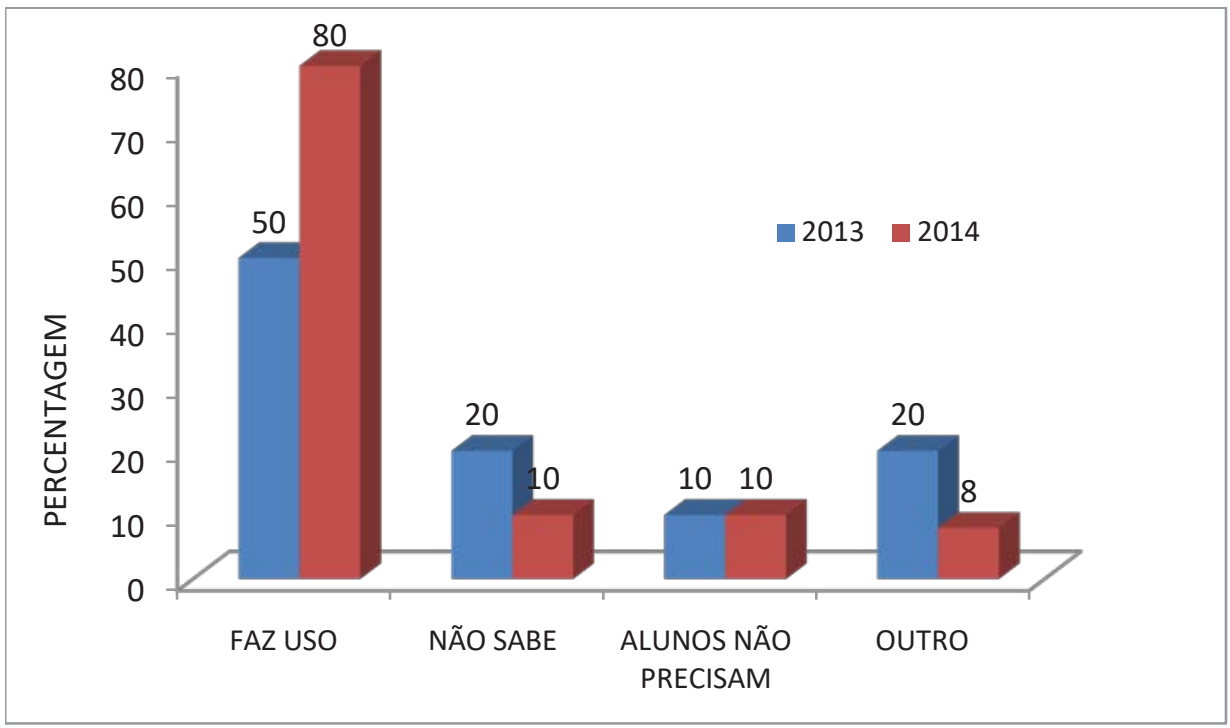

Mais professoras, após a formação, exibiram capacidade de avaliar o aluno e determinar a melhor forma de acesso ao computador.

Gráfico 13 - Uso de computador com software educativo

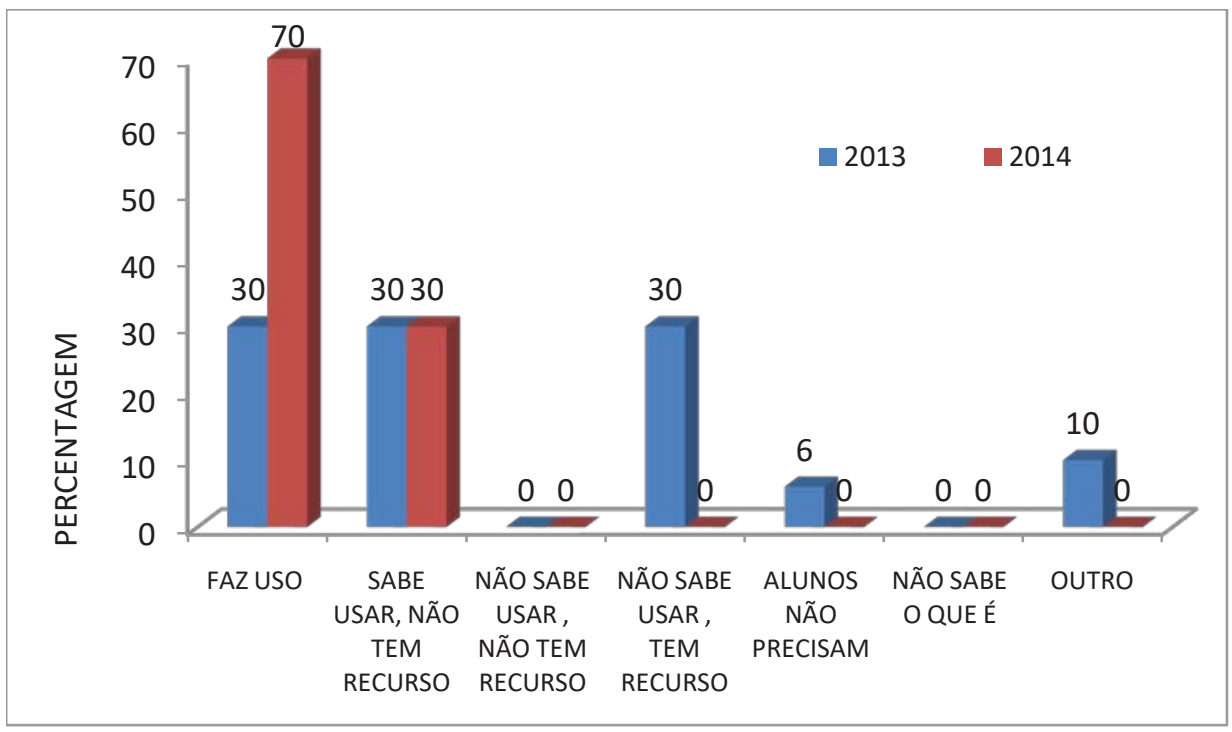


Maior número de professoras passou a usar o computador com software educativo após a formação.

Gráfico 14 - Professora usa adaptações, como órteses, pulseira de peso etc.,para facilitar o teclar.

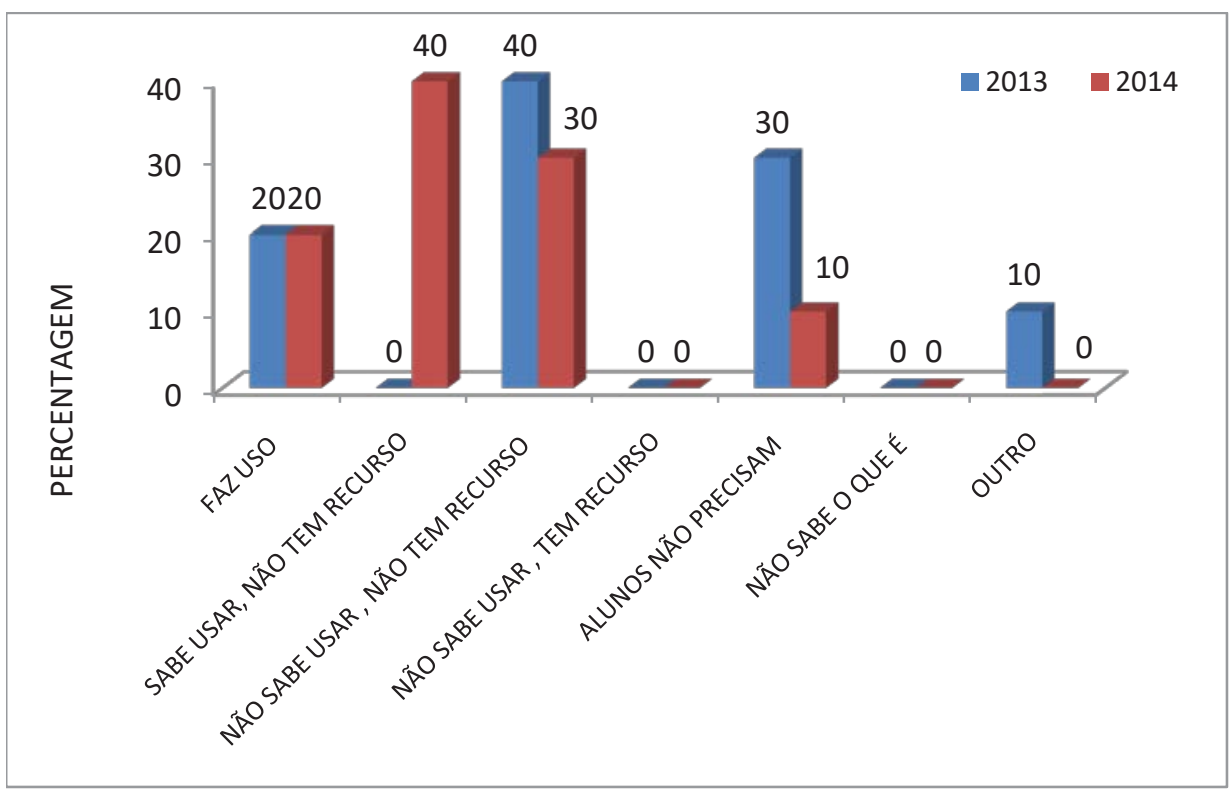

Não foi alterado, a partir da formação, o número de professoras que usam adaptaçóes para facilitar o teclar. 
Gráfico 15 - Professora usa a colmeia para teclado

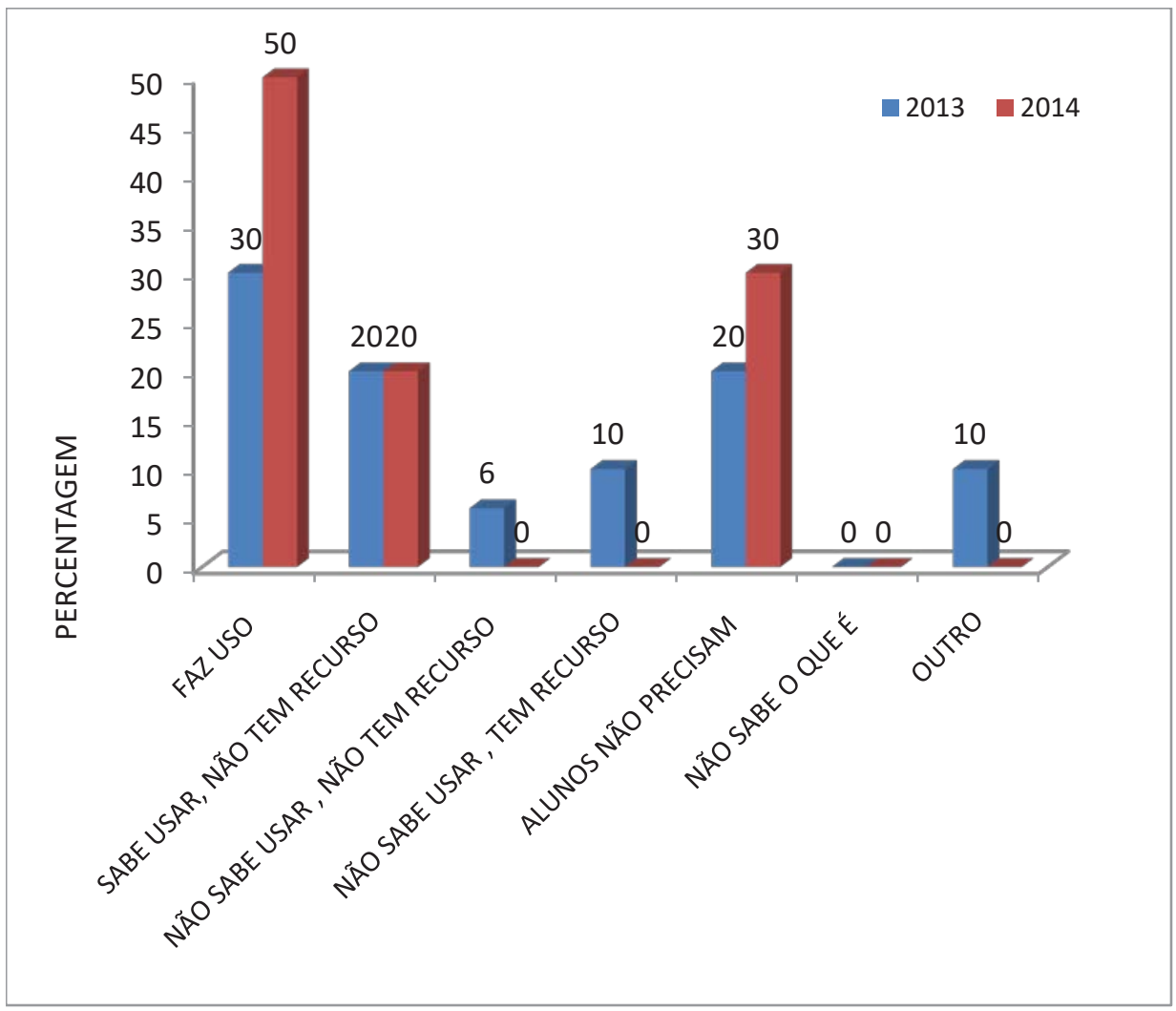

Aumentou o número de professoras que usa a colmeia para teclado após a formação. 
Gráfico 16 - Professora usa o computador com teclado expandido

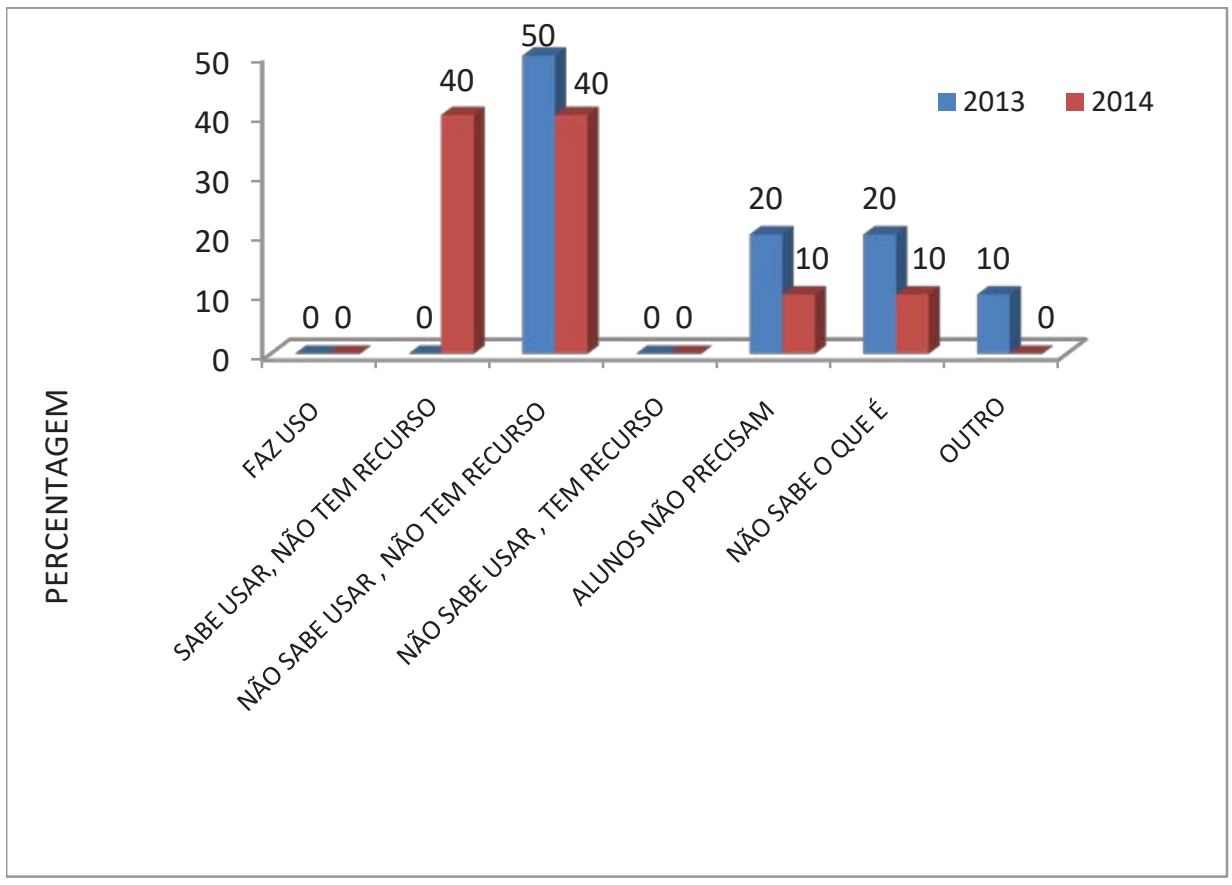

Professoras não possuem o teclado expandido em suas salas.

Gráfico 17 - Professora usa o computador com mouse adaptado

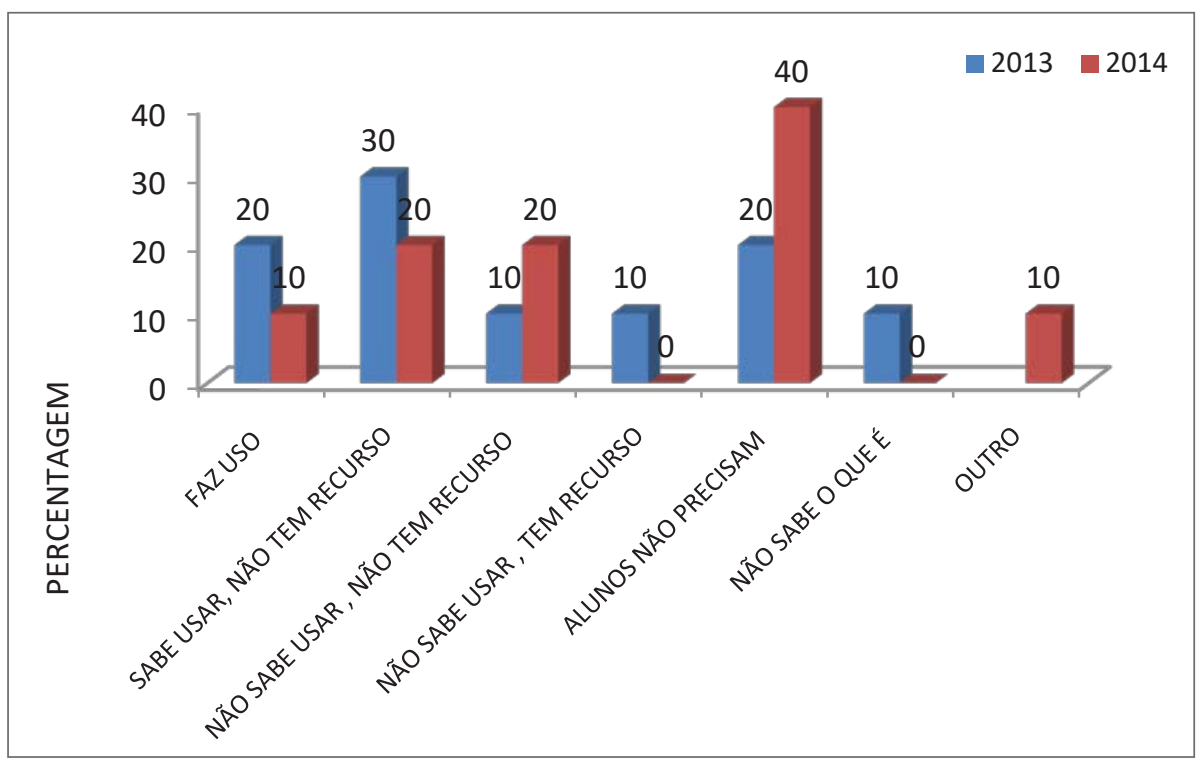


Diminuiu o número de professoras que usam o computador com mouse adaptado. Quarenta por cento das professoras não possuem mouse adaptado em suas salas.

Gráfico 18 - Professora usa computador com softwares especiais para escrita

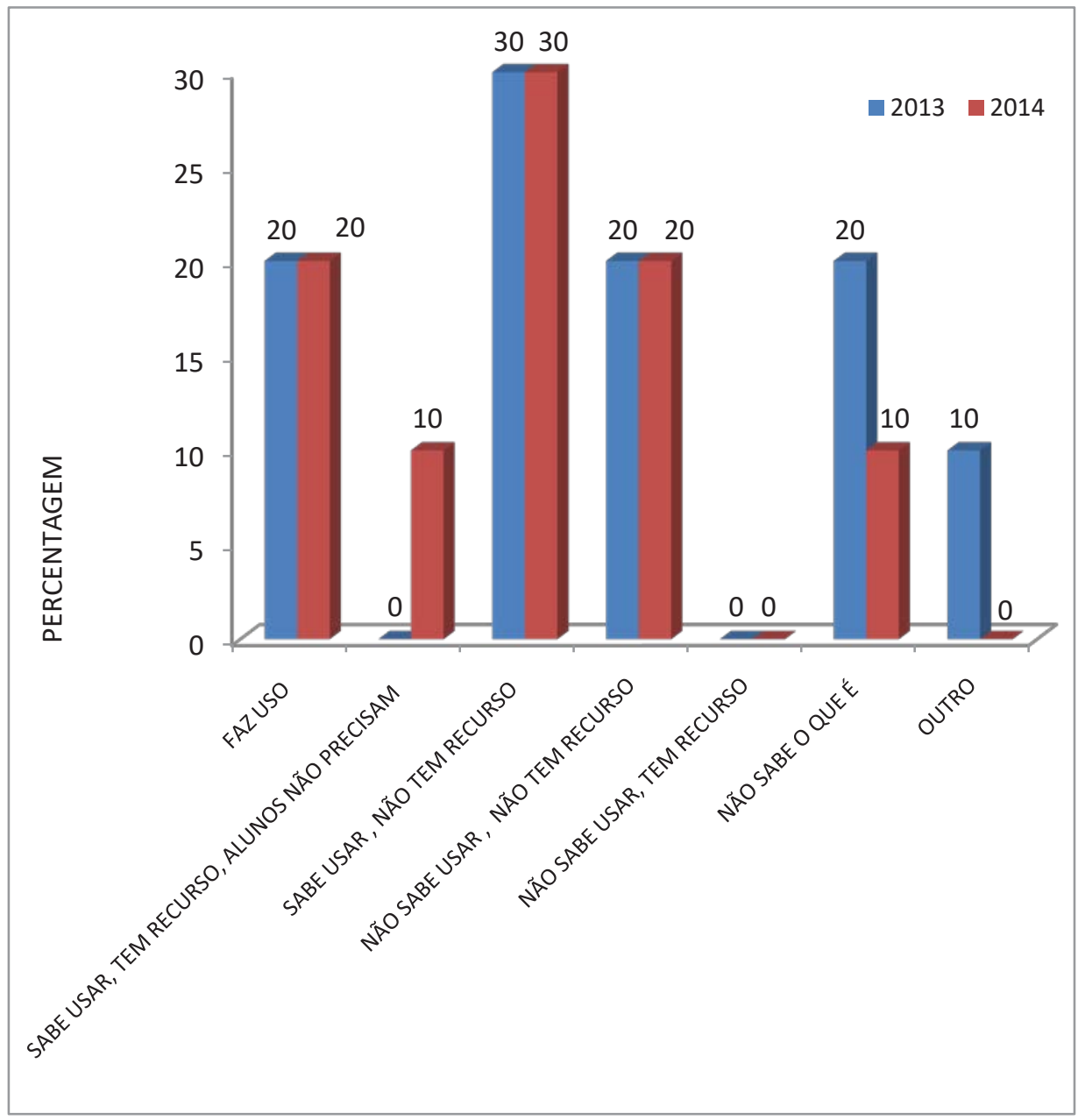

Não se alterou o número de professoras que usam o computador com softwares especiais para escrita. Cinquenta por cento das professoras não têm softwares especiais para escrita em suas salas. 
Gráfico 19 - Professora identifica as necessidades específicas do aluno diante das atividades propostas para o seu grupo de referência

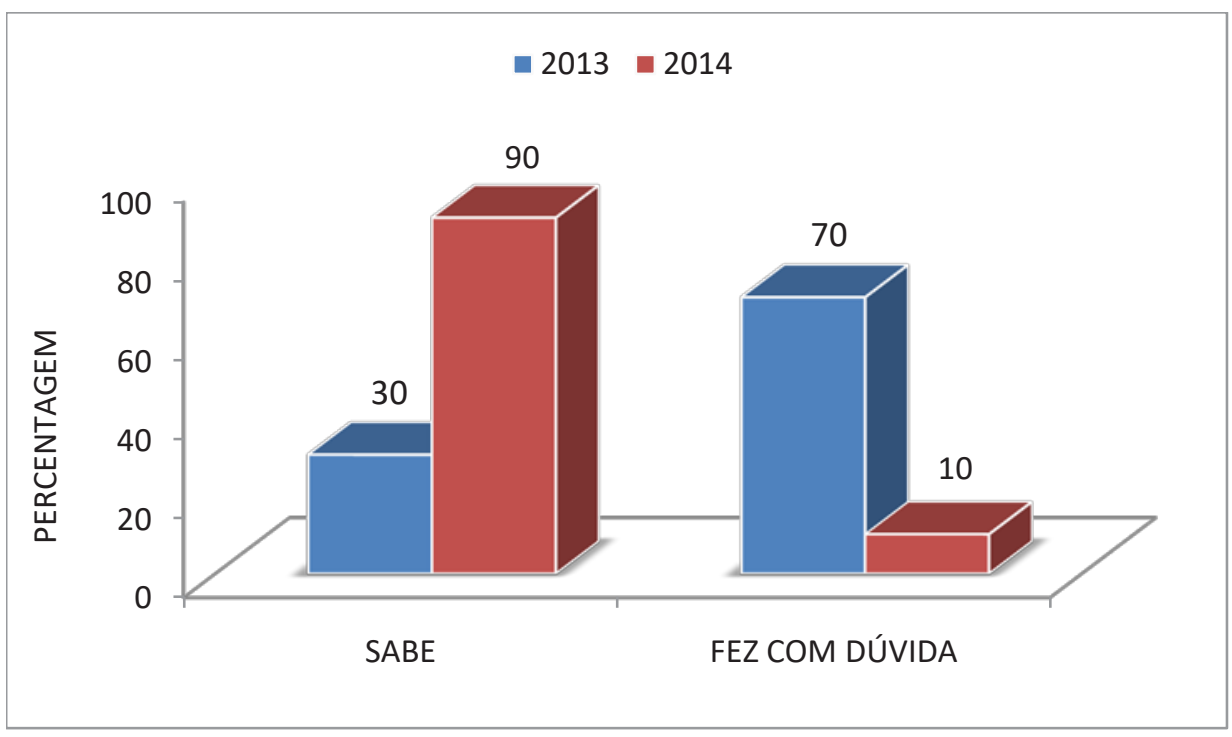

Após a formação, aumentou o número de professoras que se consideram capazes de identificar as necessidades específicas do aluno ante as atividades propostas para o seu grupo de referência. 
Gráfico 20 - Professora propõe as adaptações pedagógicas necessárias

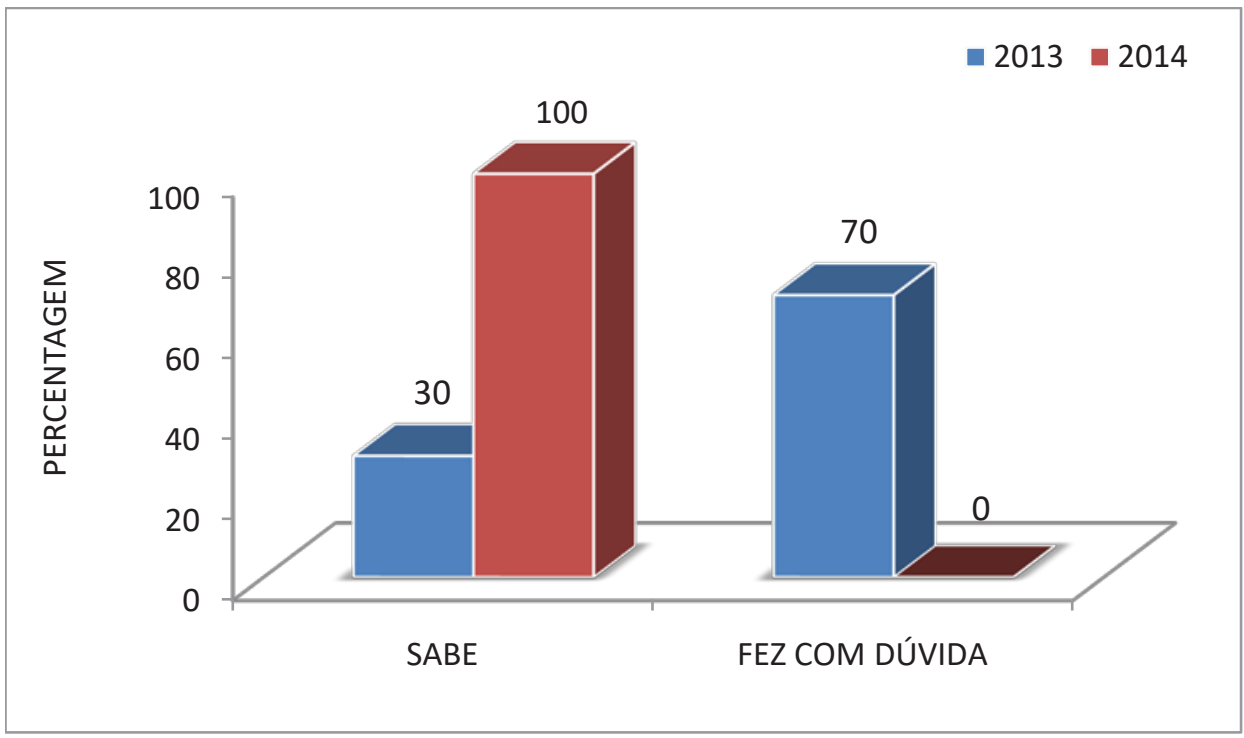

Ao final da formação, todas as professoras afirmaram saber propor as adaptações pedagógicas necessárias.

Gráfico 21 - Professora produz recursos pedagógicos adaptados às necessidades específicas dos alunos

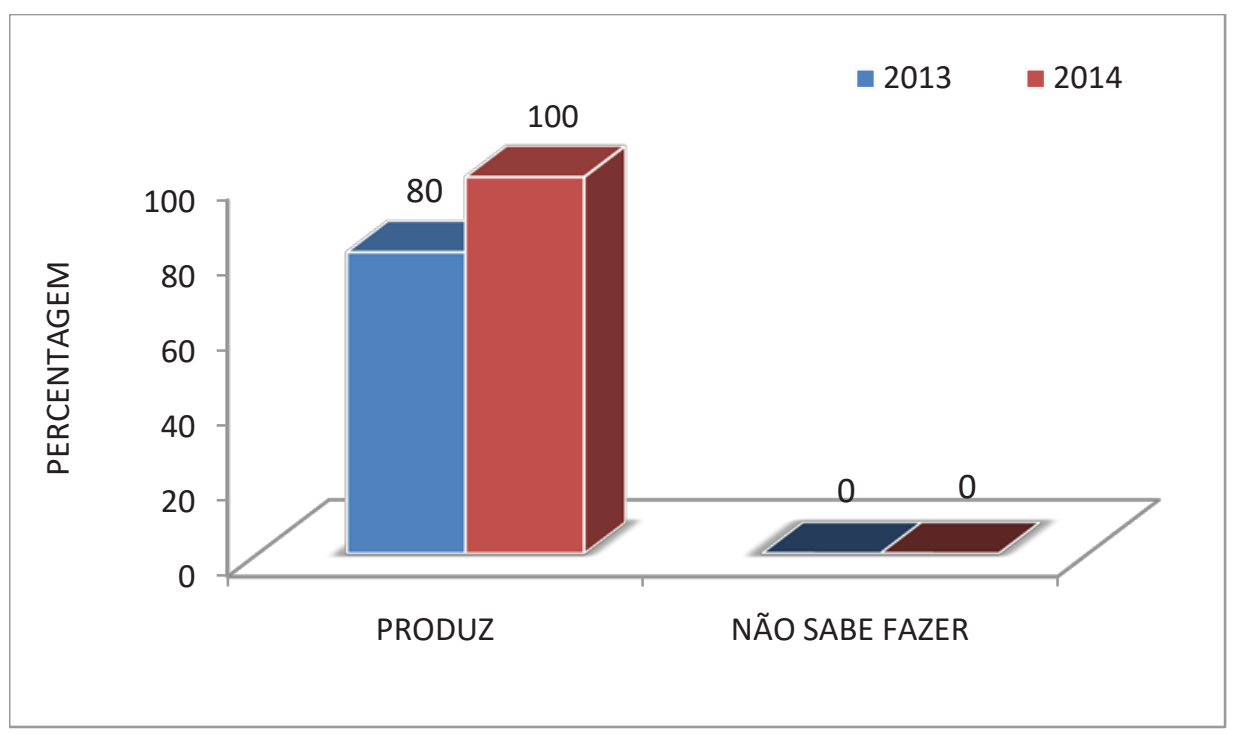


Após a formação, aumentou o número de professoras que produzem recursos pedagógicos adaptados às necessidades específicas dos alunos.

Gráfico 22 - Professora avalia o estágio de alfabetização em que o aluno se encontra (pré-silábica, silábica, alfabética ou fases de transição)

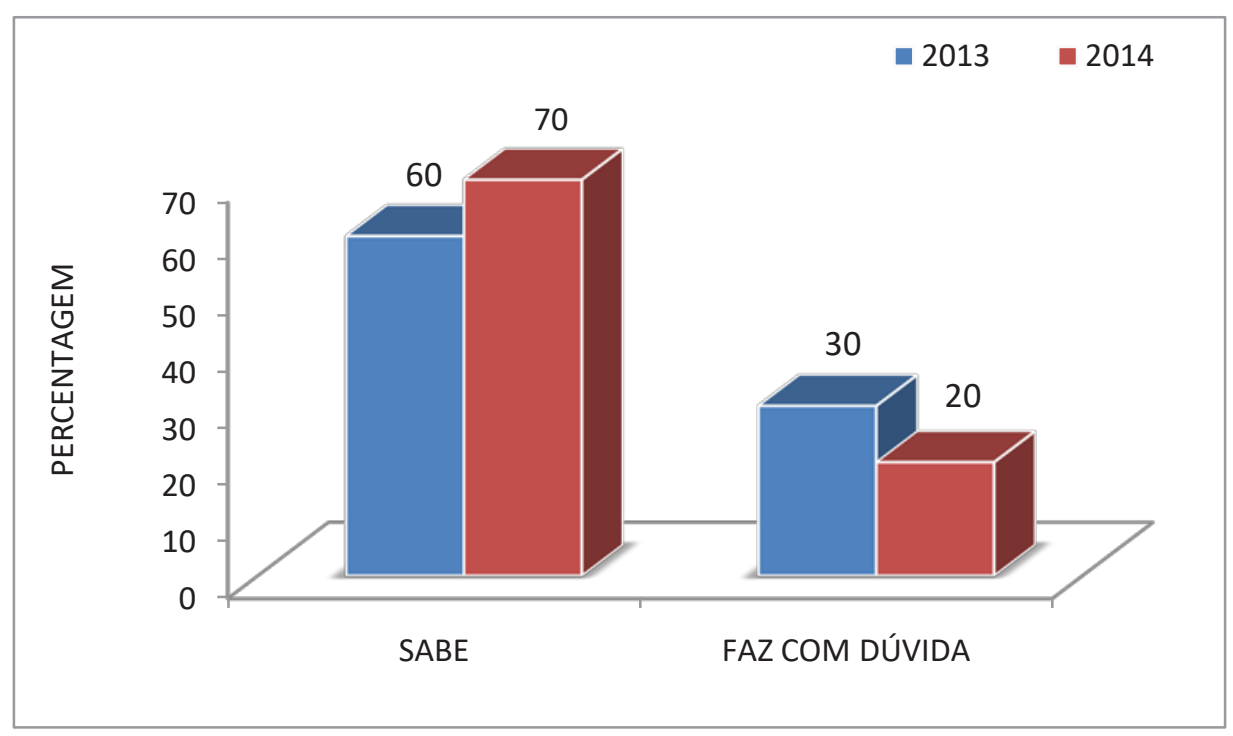

Aumentou levemente o número de professoras que sabem avaliar o estágio de alfabetização em que o aluno se encontra. 
Gráfico 23 - Professora adapta atividades de leitura e escrita

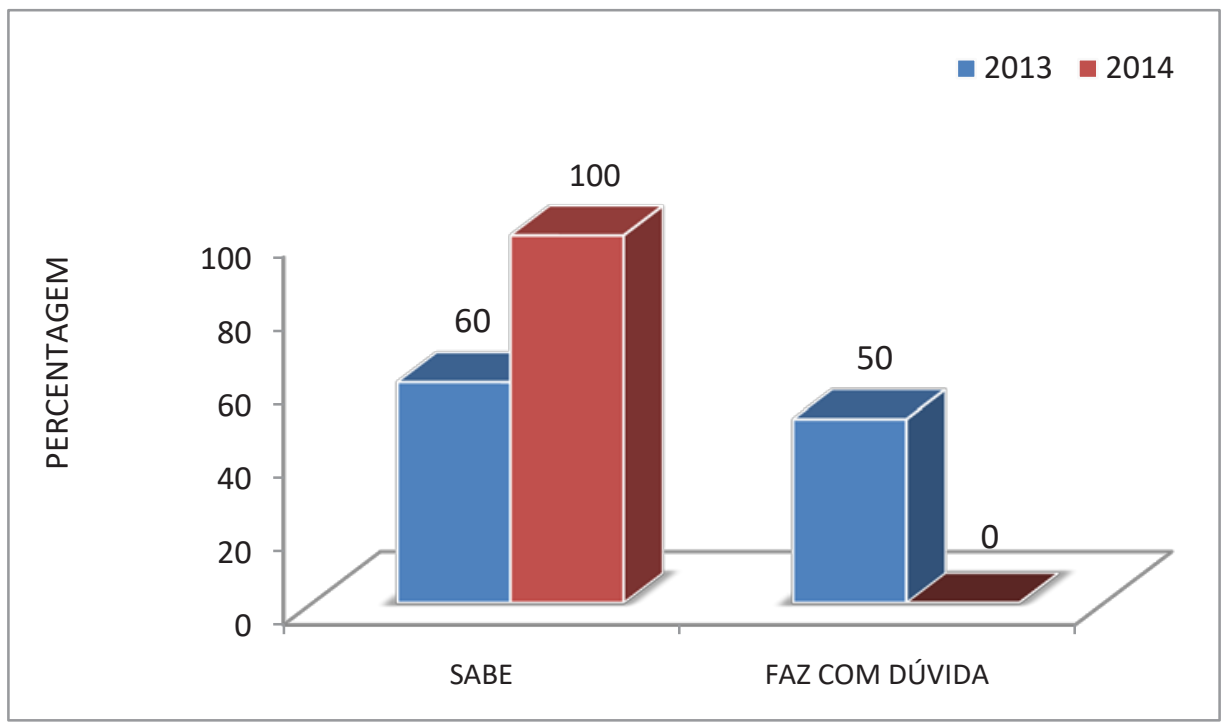

Aumentou o número de professoras capazes de adaptar atividades de leitura e escrita após a formação. Ao final de 2014, todas as professoras afirmaram saber adaptar as atividades de leitura e escrita.

Gráfico 24 - Professora adapta as atividades de matemática

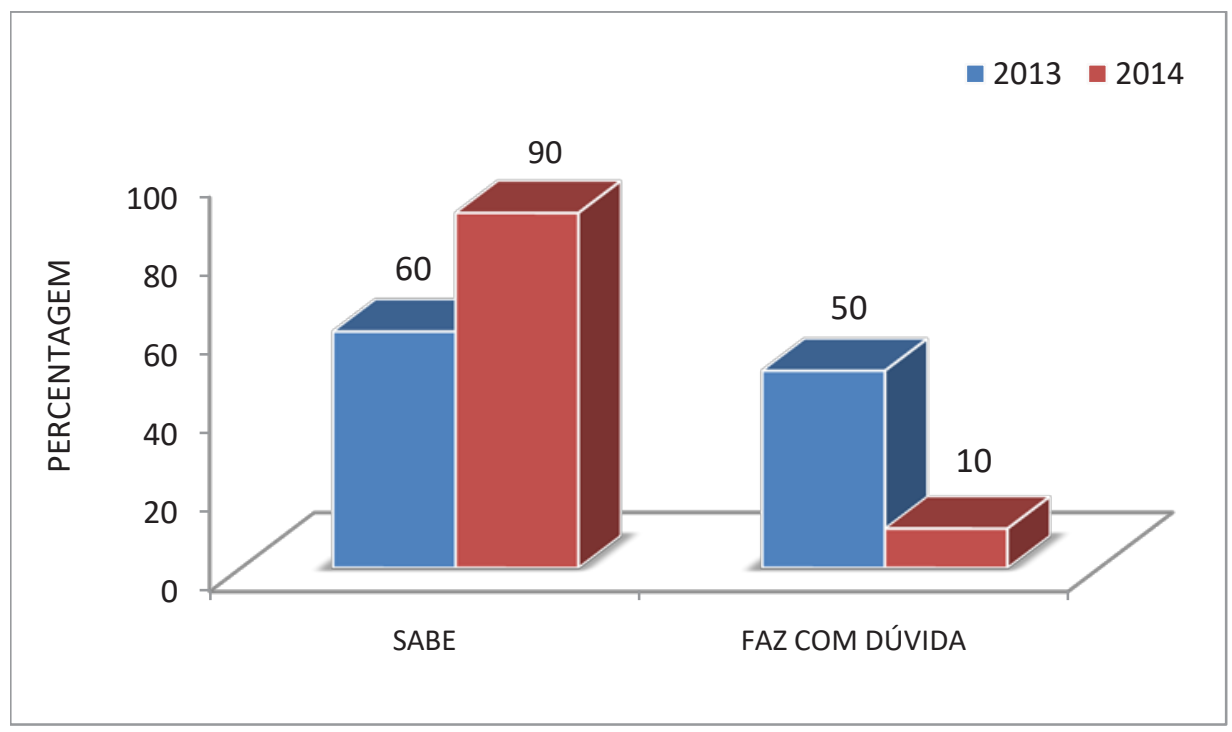


Após a formação, aumentou o número de professoras capazes de adaptar atividades de matemática.

Gráfico 25 - Professora é capaz de adaptar provas

$2013-2014$

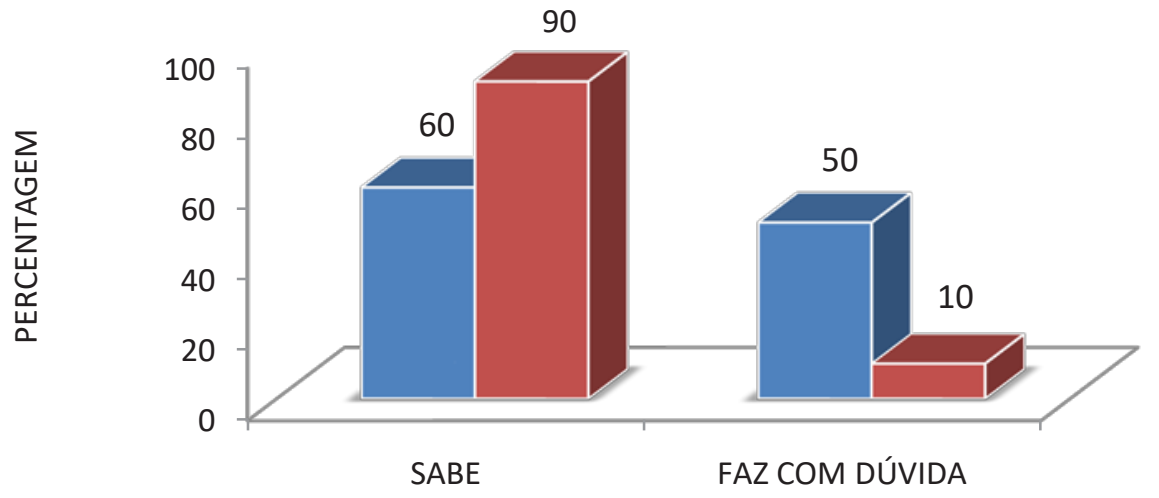

Após a formação, o número de professoras capazes de adaptar provas aumentou.

\section{Concepções e conhecimentos}

A seguir, são apresentados os dados do segundo questionário analisado. Esse instrumento teve como objetivo verificar as concepçóes e o conhecimento das professoras sobre os temas: deficiência, tecnologia assistiva, CAA, trabalho do professor com o aluno sem fala articulada ou funcional, o brincar, sugestões e comentários. Os dados resumidos estão expressos nos quadros. 


\section{Deficiência: conceito}

2013 - Alteração/prejuízo; impossibilidade; dificuldade; disfunção; área afetada; limitação, falta de habilidade e incapacidade.

2014 - Comprometimento, ausência ou limitação sensorial, intelectual, motora e comunicativa.

\section{TA: conceituação, modalidades e aplicabilidade}

2013 - Recursos ou materiais adaptados que facilitam a comunicação e a inclusão, de modo a eliminar barreiras que os alunos com deficiência encontram em sala de aula. Um dos recursos da tecnologia assistiva que favorece a comunicação e aprendizagem de alunos com dificuldades é a Comunicação Alternativa e Ampliada, contudo, há outras modalidades, tais como: pranchas de comunicação, computadores, softwares, engrossadores, lupa, colmeia, mouse adaptado e aranha-mola.

2014 - Recursos tecnológicos de alto e baixo custos que podem ser adaptados tanto para o aprendizado do aluno com deficiência, como para o favorecimento da sua comunicação, sua autonomia e independência. A CAA, as pranchas de comunicação, o Boardmaker, o lápis engrossador, os comunicadores de voz, os jogos pedagógicos e os recursos tecnológicos são modalidades de tecnologia assistiva. 
CAA: conceito, importância para inclusão, auxílio para aluno com deficiência

2013 - CAA é uma área da tecnologia assistiva que objetiva a comunicação, a leitura e a escrita do aluno mediante o manuseio de pranchas, fotos e gravuras. O seu uso é extremamente importante, pois possibilita a interação e a socialização, de maneira a favorecer a comunicação, a autonomia e a inclusão da pessoa com deficiência.

2014 - CAA é uma área de TA que proporciona a "linguagem oral" do sujeito sem fala, oportunizando outras formas de comunicação. Os recursos de CAA, como imagens, figuras, pranchas, softwares e símbolos de comunicação interativa, facilitam a comunicação do aluno especial. O Boardmaker é um programa pouco conhecido. A Comunicação Alternativa e Ampliada é fundamental para a comunicação do aluno sem fala, pois facilita/permite conhecimento, expressão e compreensão do aluno em sala de aula. $\mathrm{O}$ indivíduo que usa a CAA participa e interage mais com os seus interlocutores, utilizando cartões e símbolos para se comunicar, bem como expressa suas opiniōes com o professor e o grupo, de forma a garantir sua socialização, inclusão e independência. 


\section{Trabalho do professor junto aos alunos sem fala articulada}

2013 - Para planejar uma atividade adaptada utilizando a CAA, faz-se necessário avaliar o conhecimento do aluno, seu cotidiano e suas especificidades, com o intuito de elaborar estratégias que alcancem o aluno com ou sem deficiência. O diálogo com os profissionais do AEE é imperativo, pois, em geral, eles observam a progressão do uso do material adaptado. As angústias e apreensões fazem parte do planejamento, visto que muitos educadores encontram dificuldades em desenvolver atividades para o discente incluído. Devem ser desenvolvidas atividades que possibilitem momentos de interação, a fim de que o aluno sem comunicação oral e sem escrita funcional desperte o interesse em se relacionar. Não é uma tarefa fácil, muitas vezes angustiante, porém, o professor pode iniciar um trabalho de intensa mediação, usando pranchas de CAA e recursos adaptados para eliminar os entraves relacionados à comunicação. A interação depende do grupo, do contato estabelecido com os alunos e do planejamento pedagógico do professor.

2014 - É imperativo que o professor esteja disposto a adaptar as atividades pedagógicas para que, assim, possa atender às especificidades do alunado, e é cabível que o profissional do AEE esteja junto, apoiando-o quando necessário. $\mathrm{O}$ material adaptado chama a atenção dos outros alunos, que acabam interagindo com o aluno incluído, o que facilita sua inclusão e aprendizagem. O planejamento deve estar de acordo com a temática que está sendo dada em sala de aula e com o material específico de CAA. 
Forma de brincar e interagir do aluno com deficiência com seus pares e professores

2013 - Alguns alunos interagem de forma espontânea, já outros apresentam dificuldades de interagir e expressar seus desejos, sendo esse, talvez, um dos principais desafios enfrentados pelo professor. As dinâmicas, os jogos e as brincadeiras podem instigar o aluno a querer se relacionar, entretanto, para que funcionem, o docente precisa planejar suas atividades de modo que os objetivos propostos sejam alcançados.

2014 - Em geral, os alunos sem comunicação oral e sem escrita manual funcional estão perdidos e desinteressados. Os professores encontram muitas dificuldades, mas é preciso que se mantenham empenhados e dispostos a trabalhar com o discente incluído. No que concerne à interação, é importante avaliar as necessidades do grupo, objetivando planejar mediaçôes e adaptaçôes que contemplem todos, e que os alunos, assim como os professores resistentes, coloquem-se no lugar do outro, pois, apesar das limitações, os alunos devem brincar juntos e de maneira prazerosa. Além disso, cabe ao professor elaborar estratégias, como jogos, imagens e brincadeiras adaptadas para o aprendizado e para a inclusão da criança, provendo aulas mais dinâmicas e atividades em grupo. 
Sugestões (2013) e avaliação (2014) do trabalho na Oficina Vivencial 2013 - A proposta do projeto é interessante e animadora, pois aprofundar os conhecimentos sobre a CAA pode acarretar o aprimoramento de suas práticas. Como críticas, as professoreas salientaram que o questionário estava longo e repetitivo.

2014 - Os conteúdos teóricos contribuíram de forma significativa, pois houve uma evolução positiva, comprometimento e vontade de melhorar a prática em sala de aula. A partir da avaliação, pôde ser realizada a análise de casos por grupo, propondo alteraçôes no material que estava sendo usado em tempo real. Algumas expressaram sentimentos de dedicação, confiança, superação, desafio, decepção, amor, entre outros, acreditando que a teoria as auxiliaram na prática.

\section{Comentários adicionais}

2013 - O tempo para atender os professores, assim como a falta de recursos, ainda são as maiores dificuldades.

2014 - A experiência foi extremamente gratificante, pois apreenderam conhecimentos teóricos sobre recursos de CAA etc., todavia, faz-se necessário compreender melhor a utilização do Boardmaker e de outros sistemas e sinais de CAA, bem como entender de que maneira funcionará o projeto SRM de referência e como pô-lo em prática.

\section{Discussão}

Em síntese, após o curso de formação continuada em serviço em TA, com ênfase na CAA, percebemos modificações significativas quanto às habilidades relatadas pelos professores. Houve um aumento nas habilidades em relação ao aluno, tais como: identificação de respostas afirmativas e negativas do aluno não oralizado, identificação das necessidades específicas do aluno 
ante as atividades propostas para o seu grupo de referência, avaliação do estágio de alfabetização em que se encontra o discente e proposição das adaptações pedagógicas necessárias.

Também houve um aumento nas habilidades das professoras em relação aos recursos e materiais, como produção e uso de recursos e adaptações para a escrita, elaboração e uso social e acadêmico de pranchas de comunicação, bem como outros recursos de CAA. As professoras afirmaram que passaram a fazer adaptação de trabalhos escolares e provas.

Assim como nos estudos realizados por Ascenção (2007) e Zuttin (2008), verificamos que recursos de média e alta tecnologia, bastante necessários ao atendimento de pessoas com deficiências física e múltipla, como comunicador de voz, mouse adaptado, teclado expandido e softwares especiais para a escrita, não estão presentes em todas as SRMs. Esse talvez tenha sido um fator que contribuiu para o não desenvolvimento das habilidades para seu uso. Em contrapartida, outros recursos, como acionador de pressão e teclado com colmeia, que vêm no kit disponibilizado pelo MEC para as SRMs, passaram a ser usados por um maior número de professoras.

Em relação ao conhecimento e às concepções das professoras, percebeu-se que, no início do curso, os professores conceituaram a deficiência utilizando termos como "prejuízo, impossibilidade e incapacidade", mas, ao final do segundo ano de formação, o conceito estava associado a "comprometimento, ausência ou limitação sensorial, intelectual, motora e comunicativa”. Segundo Bersch (2007), as terminologias não definem nossa atitude perante uma pessoa com deficiência. A mesma autora destaca que a deficiência é marcada pela perda de uma das funções do ser humano, seja ela física, psicológica ou sensorial. E que um indivíduo pode ter uma deficiência, mas isso não significa necessariamente que ele seja incapaz. A incapacidade poderá ser minimizada quando o meio lhe possibilitar acessos, e a TA, principalmente a modalidade da CAA, tão enfatizada na formação, é um desses. Segundo o Comitê de Ajudas Técnicas (2007), a Tecnologia Assistiva é uma área do conhecimento, de característica interdisciplinar, que engloba produtos, recursos, metodologias, estratégias, práticas e serviços.

Em 2013 e 2014, as professoras associaram as modalidades de TA apenas aos recursos, deixando de citar que a TA também envolve estratégias, metodologias e serviços. Esses últimos são ou deveriam ser prestados por elas. Também existe uma dificuldade em distinguir as modalidades da TA. Elas 
citam, como exemplo, a CAA e seus recursos, e isso provavelmente ocorreu porque o curso enfatizou a CAA e os alunos. Com efeito, os sujeitos dos estudos de caso utilizados na formação possuíam, todos, necessidades de comunicação. Em 2014, as professoras associaram os termos "autonomia" e "independência” ao termo Tecnologia Assistiva, cujo objetivo é promover a funcionalidade, relacionada à atividade e à participação de pessoas com deficiência, incapacidades ou com mobilidade reduzida, visando a sua autonomia, independência, qualidade de vida e inclusão social (CAT, 2007).

Manzini (2013) afirma que várias pesquisas têm instigado e revelado questôes que precisam ser discutidas na formação de professores, sendo que o tema da formação de professores especialistas para pôr em uso os recursos de TA presentes nas SRMs tem recebido bastante destaque. Algumas pesquisas têm demonstrado que nem sempre os professores estão preparados para usar os recursos de TA na escola (Pelosi, 2008; Galvão Filho, 2009; Versussa e Manzini, 2009; Lourenço, 2012).

No estudo realizado por Manzini (2012), constatou-se que, dos 32 recursos apresentados no questionário aplicado, em relação ao conhecimento dos recursos e equipamentos de Tecnologia Assistiva para alunos com deficiência física, apenas 14 deles são conhecidos por pelo menos $50 \%$ dos professores das salas de recursos.

Em relação ao uso e à importância da CAA para a inclusão, as professoras declararam que a consideram fundamental para o desenvolvimento, a comunicação e a autonomia do aluno sem fala, e reconhecem-na como uma área/modalidade de TA.

Quanto ao trabalho do professor junto a aluno sem fala articulada ou funcional em 2013, as professoras reconheceram a importância da avaliação das necessidades e especificidades deste para o trabalho com a CAA, porém, consideram-na como uma "tarefa difícil e angustiante". São muito comuns, em um primeiro momento, os sentimentos de angústia, de incapacidade e de medo perante a necessidade de atendimento a um aluno com deficiência sem fala articulada, por exemplo. Esse desconhecimento a respeito dos aspectos peculiares da deficiência e de suas potencialidades pode afastar o professor desse tipo de experiência por lhe suscitar estranheza (Correia, 1999; Beyer, 2003; Rocha et al., 2003), impedindo-o de desenvolver uma prática pedagógica sensível às necessidades do aluno especial incluído (Pletsch, 2009). Diferentemente do que revelaram no início do curso, as professoras ressalta- 
ram em 2014 que a CAA precisa constar no planejamento do professor e que as adaptações devem estar de acordo com as especificidades dos alunos, pois acabam por beneficiar a turma toda.

Atuar com alunos que necessitam de conhecimentos sobre educação especial exige do professor maior atenção em relação à sua prática. Além de adaptações do espaço físico, de serviços de apoio, de um material pedagógico adequado, dos recursos e serviços de TA ou de qualquer alteração necessária para facilitar o processo de aprendizagem, o discente usuário de CAA necessita de intervençóes e de algumas adaptações na apresentação dos conteúdos. Assim, o professor que possui um aluno incluído em sua sala de aula não pode deter-se em planejamentos padronizados de ensino. Ao contrário, as necessidades específicas também criam a essencialidade de novas e diferentes formas de apresentar o conteúdo escolar, ação que proporciona maior compreensão por parte desse aluno e dos demais.

No entanto, nem todos os professores estão preparados para adequar a sua forma de ensinar às características e necessidades particulares desses discentes ou não possuem um serviço de apoio de um profissional especializado, que os auxilie no atendimento em sala de aula. Assim, alunos que precisam de intervençóes específicas ou de suporte imediato não são logo atendidos, o que prejudica ainda mais seu entrosamento na dinâmica da turma (Macedo, 2009). Galvão Filho (2009), em tese de doutorado desenvolvida em Salvador, referiu que os participantes da pesquisa também careciam de informações sobre os recursos de Tecnologia Assistiva, sendo necessário investimento e formação profissional continuada desses docentes.

Quanto à avaliação da proposta, comentários e sugestôes, as professoras, em 2013, avaliaram o projeto como "interessante e animador" e, em 2014, afirmaram que os conteúdos e a metodologia haviam contribuído para a melhora de sua prática.

Estudos desenvolvidos por Martins (2003), Oliveira (2003), Lauro et al. (2003), Gomes e Barbosa (2006), Mori (2003), Pelosi (2008), Pletsch (2009), Galvão Filho (2009) e Schirmer (2012) apontam para a necessidade de formação continuada em serviço, informação e apoio aos educadores, bem como mudanças nos processos avaliativos, maior envolvimento da família e de outros profissionais, melhora dos recursos materiais e das condições de trabalho para o professor e abordagens de formação que utilizem metodolo- 
gias diferenciadas. Mas também mostram que a inclusão responsável e gradativa é possível e pode ser bem-sucedida.

\section{Conclusão}

O levantamento das habilidades e o conhecimento do grupo de professores participantes do projeto foi muito importante na elaboração do curso. A formação ofertada nos anos de 2013 e 2014 foi estruturada de maneira a possibilitar aos participantes a reflexão de suas práticas pedagógicas cotidianas, tendo como abordagem educacional uma metodologia problematizadora. Os conteúdos formativos foram organizados a partir das necessidades apontadas pelos professores nos estudos de caso e filmagens e enfatizaram o planejamento, a execução e a avaliação de serviços e dos recursos da Tecnologia Assistiva, com ênfase na CAA, pertinentes ao trabalho realizado pelo Atendimento Educacional Especializado. Percebe-se, com os resultados, que houve uma apropriação pelos professores com relação à avaliação, ao planejamento, à elaboração e ao uso de recursos de baixa tecnologia, sobretudo na CAA e no material pedagógico adaptado ou especialmente produzido.

Diante disso, acreditamos que um importante fator que pode prejudicar o processo de inclusão é a ausência de uma formação inicial e continuada adequada. Essa formação pode oferecer ao professor - tanto o que atuará na rede de ensino comum como o especializado -, entre outras coisas, prática e conhecimentos consistentes sobre o processo de ensino e de aprendizagem de alunos com deficiência, bem como a compreensão das inúmeras possibilidades e potencialidades de cada aluno, principalmente quando este recebe o apoio dos recursos de Tecnologia Assistiva. 